\title{
iaspm@journal
}

ISSN 2079-3871

\section{RevieW | Popular Music Matters: Essays in Honour of Simon Frith}

Lee Marshall and Dave Laing Eds.

Farnham: Ashgate, 2015

ISBN 978-1-4724-2179-1

\section{Motti Regev \\ Open University of Israel \\ mottire@openu.ac.il}

As the title suggests, this collection presents articles written as tribute to the work of Simon Frith - pioneer, leader, and highly influential scholar in the field of popular music studies. Given Frith's versatility in terms of research topics, his parallel career as critic, as well as the editors' rightful decision to include informative accounts of his career, the book is divided into three parts. The chapters in Part 1 tackle issues revolving around the music industry, including technology, Part 2 concentrates on various dimensions of Frith's career, and Part 3 focuses on the subjects of aesthetics and value in popular music. The chapters are bookended by a charming personalized Preface, as well as Afterword by, respectively, renowned critic Robert Christgau and the sadly and prematurely departed scholar Andrew Goodwin.

Some of the chapters engage directly with the work of Frith, while others address topics that have been central to his work. Whether intended by the editors or not, the overall effect of this book is to offer a sort of bird's eye view, a condensed landscape, of major issues that have been central to the field of popular music studies in its first thirty years. Rock music and class (in a chapter by Barbara Bradby), creative work of musicians (by Sarah Baker), music industry research (by Michael L. Jones) as well as ruminations about music collecting in the age of streaming and cloud-storage (by Lee 
Marshall) reflect typical concerns with the changing nature of popular music production, distribution, technology and consumption.

Focusing more directly on the music itself, Philip Tagg calls for a new approach to the study of music that takes advantage of technological developments in order to examine the actual sonorities of music, in contrast to music notation. In a similar vein, Antoine Hennion explains how his well-known notion of listening as an act of music performance should be applied to the way music is consumed through new digital media. From a different angle Pete Astor and Keith Negus provide a fresh look at lyrics - their function in popular music and the practice of writing them. Turning to the issue of musical value, John Street offers an insightful analysis of the interplay between the practice of value judgments and research about the production of value, based on Frith's parallel work as chair of the Mercury Music Prize and as a scholar examining how musical value is decided and performed - especially in Performing Rites (Frith 1998). In the final chapter of the book, Jason Toynbee mourns in a romantic Marxist manner the decline of the revolutionary spirit that characterized much of rock, pop and soul from the 1960s until the 1980s. As he kindly elaborates and acknowledges my disagreement with his thesis about the decay of pop-rock (Regev 2013), I will just say that in my view the perceived decline of critique in rock is closely connected to the colossal cultural success of pop-rock to become the major global musical culture of late modernity.

In a way, I find the chapters in Part 2 to be the most intriguing. Examining and reviewing several aspects of Frith's professional career, they amount to an analytic overview of what it meant to be a pop-rock scholar when the field of popular music studies was struggling for recognition and legitimacy. Martin Cloonan thus points to the ever existing, underlying political dimension in the work of Frith. Reflecting the double personality of scholar and fan-critic that characterizes many popular music researchers, the Nordic team responsible for the definite book on rock criticism (Lindberg et al. 2007) offers a penetrating look at the work of Frith as a music critic. Dave Laing, lucid as he always is and accurately referring to Frith's work as "low theory", provides a detailed review of Frith's career in terms of institutional affiliations and intellectual inclinations. It is a clear and sharp exposure of the multidisciplinary nature of popular music studies. Following on the subject of theory, Peter J. Martin (126) excavates in a highly sophisticated manner Frith's work for the two main sociological approaches that informed it:

From Marxism, the mediations of the industry as it seeks to classify music and sell it as a commodity to targeted consumers; from symbolic interactionism, the idea that the "meaning" of music depends as much on the discourse that surrounds it as on the sounds themselves.

For all its fine contributions, the book remains however, in the end, a very British affair. Regretfully, the editors did not find room to include chapters by scholars from, or addressing issues relating to, popular music from Latin America, East Asia, Africa or Southern Europe. Frith's stature extends beyond the Anglo-American and North European axis, and his writing tackled more than once topics such as "world music" 
or globalization. As it stands, the Simon Frith of this book is primarily, perhaps even exclusively, a British figure. I am not sure IASPM members, as a community of scholars and readers of this journal, share this view.

\section{References}

Frith, S. 1998. Performing Rites: On the Value of Popular Music. Cambridge, MA: Harvard University Press.

Lindberg, U., Guðmundsson G., Michelsen, M. and Weisethaunet, H. 2005. Rock Criticism from the Beginning: Amusers, Bruisers \& Cool Headed Cruisers. New York: Peter Lang.

Regev, M. 2013. Pop-Rock Music: Aesthetic Cosmopolitanism in Late Modernity. Cambridge: Polity. 